\title{
ANALISIS PREDIKSI JUMLAH PENDUDUK DI KOTA PASURUAN MENGGUNAKAN METODE ARIMA
}

\author{
Analysis of Population Prediction in Pasuruan City Using ARIMA \\ Ilmiatul Mardiyah ${ }^{1}$, Wika Dianita Utami ${ }^{2}$, Dian Candra Rini Novitasari ${ }^{3}$, Moh. \\ Hafiyusholeh $^{4}$, Dewi Sulistiyawati ${ }^{5}$ \\ 1,2,3,4 Prodi Matematika, Fakultas Sains dan Teknologi, UIN Sunan Ampel Surabaya \\ ${ }^{5}$ Badan Pusat Statistik Kota Pasuruan \\ 1,2,3,4 Jln. Ahmad Yani No.117, Surabaya, 60237, Indonesia \\ ${ }^{5}$ Jln. Panglima Sudirman No. 84, Pasuruan, 67115, Indonesia \\ Corresponding author e-mail: 2*wikadianita@uinsby.ac.id
}

\begin{abstract}
Abstrak
Laju pertumbuhan penduduk di Kota Pasuruan pada tahun 2019 sebesar $0.68 \%$ dengan jumlah penduduk 200.422 jiwa. Tingginya pertumbuhan penduduk dapat mempengaruhi kepadatan penduduk. Penelitian ini bertujuan untuk memprediksi pertumbuhan penduduk Kota Pasuruan menggunakan metode ARIMA (Autoregressive Integrated Moving Average). Metode ARIMA adalah cara prediksi data deret waktu yang memiliki tiga model, yaitu AR (Autoregressive), MA (Moving Average), ARMA (Autoregressive Moving Average). Metode ini memiliki parameter $(\mathrm{p}, \mathrm{d}, \mathrm{q})$ dapat diketahuidari plot ACF dan PACF untuk memastikan model yang akan digunakan untuk prediksi. Dalam penelitian ini data yang digunakan merupakan data penduduk Kota Pasuruan tahun 1983 sampai tahun 2019 sejumlah 37 data. Dari data tersebut didapatkan ARIMA model $(1,1,1)$ dengan jumlah penduduk Kota Pasuruan pada tahun 2020 adalah 203.221 jiwa, didapatkan nilai MSE 10542507.06 dan MAPE 1.52\%.
\end{abstract}

Kata Kunci : Penduduk, Prediksi, Time Series, ARIMA

\begin{abstract}
The population growth rate in Pasuruan city in 2019 is $0.68 \%$ with a population of 200.422 people. High population growth can affect population density. This study aims to predict the population growth of Pasuruan city using the ARIMA (Autoregressive Integrated Moving Average) method. The ARIMA method is a time series data prediction method that has three models, namely AR (Autoregressive), MA (Moving Average), ARMA (Autoregressive Moving Average). This method has parameters $(p, d, q)$ that can be found from the ACF an PACF plots to determine which model will be used for prediction. In this study, the data used were population data from Pasuruan city from 1983 to 2019 with 37 data. From this data, the ARIMA model $(1,1,1)$ with the total population of Pasuruan city in 2020 is 203.221 people, the MSE value is 10542507.06 and MAPE $1.52 \%$.
\end{abstract}

Keywords: Population, Forecasting, Time Series, ARIMA

\begin{tabular}{l} 
Article info: \\
\hline Submitted: $25^{\text {th }}$ March 2021 \\
\hline How to cite this article: \\
I. Mardiyah, W. D. Utami, D. C. R. Novitasari, M. Hafiyusholeh, and D. Sulistiyawati, “ANALISIS PREDIKSI JUMLAH PENDUDUK DI \\
KOTA PASURUAN MENGGUNAKAN METODE ARIMA", BAREKENG: J. Il. Mat. \& Ter., vol. 15, no. 03, pp. 525-534, Sep. 2021.
\end{tabular}

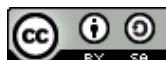

This work is licensed under a Creative Commons Attribution-ShareAlike 4.0 International License.

Copyright @ 2021 Ilmiatul Mardiyah, Wika Dianita Utami, Dian Candra Rini Novitasari, Moh. Hafiyusholeh, Dewi Sulistiyawati, 


\section{PENDAHULUAN}

Penduduk adalah warga yang bertempat tinggal di suatu daerah dengan mengikuti aturan-aturan yang telah ditentukan dan memiliki status sebagai pribadi, anggota keluarga, anggota masyarakat, warga negara, yang lahir secara turun-temurun [1]. Pertambahan penduduk adalah perubahan jumlah penduduk dari waktu kewaktu dengan faktor kelahiran, kematian, dan transmigrasi yang mengakibatkan jumlah penduduk berkurang dan bertambah pada suatu daerah [2]. Tingginya angka pertambahan jumlah penduduk di Indonesia menghambat proses pembangunan dan perkembangan suatu negara, seperti ekonomi, pendidikan, dan dapat meningkatnya angka kemiskinan [3]. Setiap tahun pertumbuhan penduduk akan meningkat, Indonesia termasuk kedalam lima negara dunia dengan penduduk terbanyak, saat ini Indonesia berada pada peringkat ke empat setelah negara Cina, India, dan Amerika Serikat. Indonesia berada pada peringkat pertama di Benua Asia dengan jumlah penduduk terbanyak [4]. Berdasarkan Sensus Penduduk yang dilakukan pada tahun 2020, penduduk Indonesia sebesar 270.20 juta jiwa [5].

Berdasarkan data Sensus Penduduk pada tahun 2020, Pulau Jawa menempati urutan pertama dengan jumlah penduduk terbanyak yang tersebar di 6 provinsi, salah satunya Provinsi Jawa Timur. Provinsi Jawa Timur mempunyai wilayah yang terluas di antara 6 provinsi di Pulau Jawa. Provinsi yang memiliki jumlah penduduk terbesar kedua adalah provinsi Jawa timur setelah Jawa Barat dengan jumlah penduduk sebesar 40.67 juta jiwa [6]. Provinsi Jawa Timur terdiri dari beberapa Kota dan Kabupaten, salah satunya Kota Pasuruan yang memiliki jumlah penduduk 208.006 jiwa pada tahun 2020. Pertumbuhan jumlah penduduk Kota Pasuruan pada tahun 2019 sebesar 200.422 jiwa [7]. Semakin tinggi pertumbuhan akan mempengaruhi terjadinya kepadatan penduduk sehingga akan mengakibatkan persoalan dalam pembenahan ruang. Daerah yang memiliki penduduk padat dan persebaran tidak sesuai akan menimbulkan berbagai masalah seperti masalah tempat tinggal, lapangan pekerjaan, pendidikan, ekonomi, keamanan, dan mengakibatkan kerusakan lingkungan [8]. Kota Pasuruan memiliki 4 Kecamatan dan 34 Kelurahan, jumlah penduduk terbesar terletak di Kecamatan Purworejo [7].

Salah satu cara yang bisa dilakukan untuk mengurangi kepadatan penduduk di Kota Pasuruan adalah peramalan atau prediksi pertumbuhan jumlah penduduk. Hasil prediksi dapat dijadikan pemerintah Kota Pasuruan dalam mengantisipasi munculnya permasalahan yang disebabkan untuk memperkirakan kejadian dimasa depan yang didasarkan pada data histori dan peramalan sebagai cara untuk menentukan suatu hasil yang lebih akurat. Ada banyak cara yang bisa digunakan dalam melakukan peramalan [9]. Dalam melakukan peramalan ada beberapa model, yaitu model berdasarkan matematika statistik seperti pemulus eksponensial atau eksponential smooting, model moving average, dan model ARIMA (Box-Jenkins). Model berdasarkan kecerdasan buatan seperti neural network, alogaritma genetik, simulated anneeling, dan klasifikasi [10], [11] . Metode ARIMA adalah salah satu metode yang mudah dan cepat dengan menggunakan pola data yang ada, selain itu metode ARIMA mempunyai tingkat kedekatan yang tinggi dan mempunyai nilai kesalahan yang kecil karena proses perhitungan yang secara bertahap. Metode ARIMA memiliki tiga metode yaitu, AR (Autoregressive), MA (Moving Average), ARMA (Autoregressive and Moving Average) [12].

Analisis deret berkala (Time Series Analysis) merupakan cara yang digunakan untuk memilih pola data yang dikumpulkan dari waktu kewaktu secara berurutan. Pola data tersebut diekstrapolasikan untuk melakukan forecting di waktu yang akan datang. Analisis time series didasarkan pada serangkaian nilai variabel yang telah lalu dimana variabel yang digunakan berdasarkan urutan waktu, seperti mingguan, bulanan, tahunan yang teratur[9], [13].

Terdapat beberapa penelitian terdahulu yang menggunakan metode Autoregressive Moving Average (ARIMA) dalam melakukan prediksi, antara lain peramalan pertumbuhan penduduk Kabupaten Situbondo didapatkan ARIMA model $(3,3,1)$ [17]. Penelitian lain tentang peramalan peningkatan jumlah penduduk berdasarkan jenis kelamin dengan nilai MAPE untuk laki-laki sebesar 7.6281e-05 dan nilai MAPE untuk perempuan sebesar 8.4849e-05 [18]. Penelitian lain tentang peramalan harga harga bitcoin didapatkan model $(0,2,1)$ dengan MAPE sebesar 4.53\% [19]. Penelitian lain tentang prediksi persediaan bahan baku produksi plastik blowing dan inject didapatkan ARIMA model $(0,2,2)$ dengan MAPE $0.520 \%$ untuk plastik blowing dan plastik inject $(0,2,2)$ dengan MAPE $0.571 \%$ [20]. Metode ARIMA baik digunakan untuk meramalkan laju inflasi daripada metode AR, MA degan nilai Sum Squared Error (SSE) masing-masing 23.22, 31.51, dan 577,36 didapatkan ARIMA model $(1,1,1)[21]$.

Berdasarkan uraian diatas, maka peneliti tertarik untuk menentukan model terbaik jumlah penduduk Kota Pasuruan menggunakan metode ARIMA dan mengetahui hasil peramalan atau prediksi jumlah penduduk Kota Pasuruantahun 2020 menggunakan metode ARIMA. 


\section{METODE PENELITIAN}

Dalam penelitian ini data yang digunakan merupakan data sekunder, data yang digunakan merupakan data jumlah penduduk Kota Pasuruan dari tahun 1983-2019. Data diambil dai Badan Pusat Statistika (BPS) Kota Pasuruan, tepatnya dari website https://pauruankota.bps.go.id/ [7].

Tabel 1. Data Penduduk Kota Pasuruan Tahun 1983 sampai 2019

\begin{tabular}{rcc}
\hline No. & Tahun & Jumlah Penduduk \\
\hline 1. & 1983 & 131602 \\
\hline 2. & 1984 & 132551 \\
\hline$\vdots$ & & $\vdots$ \\
\hline 36. & 2018 & 199078 \\
\hline 37. & 2019 & 200422 \\
\hline & & Sumber data: $[7]$
\end{tabular}

Dalam melakukan peramalan atau prediksi yang menggunakan data time series dengan metode ARIMA. Dilakukan beberapa tahap yaitu identifikasi model, estimasi parameter, uji diagnotik dan prediksi.

1. Mengumpulkan data jumlah penduduk Kota Pasuruan dari tahun 1983 sampai dengan tahun 2019.

2. Identifikasi Model

Dalam mengidentifikasi model pada metode ARIMA data yang digunakan harus memenuhi syarat stasioner, jika data tersebut belum memenuhi syarat stasioner maka data tersebut harus dilakukan proses stasioner terhadap varians dan rata-rata (mean) [22].

Data time series yang belum stasioner, maka data tersebut harus ditransformasikan menggunakan Box-Cox Transformation, dengan persamaan Box-Cox Transformation sebagai berikut [23].

$$
T\left(Z_{t}\right)^{\prime}=\frac{z_{t}^{\lambda}}{\lambda}
$$

Keterangan:

$T\left(Z_{t}\right)$ : nilai data yang ditransformasikan

$Z_{t} \quad$ : nilai data waktu ke-i

$\lambda \quad$ : nilai estimasi parameter transformasi

Data time series yang belum memenuhi syarat, maka data tersebut harus dilakukan proses differencing, untuk mencari perbedaan data satu dengan data sebelumnya secara berurutan. Persamaan differencing sebagai berikut [23].

$$
Z_{t}^{\prime}=Z_{t}-Z_{t-1}
$$

Keterangan:

$Z_{t}^{\prime} \quad$ : nilai data yang di differencing

$Z_{t} \quad$ : nilai data waktu ke-i

Jika data sudah stasioner, maka bisa didapatkan model tentatif ARIMA (p,d,q) dengan p adalah lag yang melebihi batas signifikansi di plot Partial Autorrelation Function (PACF), d adalah tingkat differencing yang dilakukan, $\mathrm{q}$ adalah lag yang melewati batas signifikansi di plot Autocorrelation Function (ACF).

Autoregressive adalah model dimana variabel dependen dipengaruhi oleh nilai variabel dependen itu sendiri karena data yang digunakan merupakan data tunggal berikut [14].

$$
X_{t}=\emptyset_{0}+\emptyset_{1} X_{t-1}+\emptyset_{2} X_{t-2}+\cdots+\emptyset_{p} X_{t-p}+\alpha_{t}
$$

Keterangan:

$X_{t} \quad$ : deret waktu t

$X_{t-i} \quad:$ deret waktu t-i

$\alpha_{t} \quad$ : nilai kesahan waktu $\mathrm{t}$

$\emptyset_{0} \quad$ : konstanta

$\emptyset_{i} \quad$ : koefisien dari autoregressive 
Moving Average adalah model yang mengukur autokorelasi antar nilai kesalahan atau residual. Secara umum MA berordo q, dengan bentuk MA (q) sebagai berikut [15].

$$
X_{t}=e_{t}-\theta_{1} \alpha_{t-1}-\theta_{2} \alpha_{t-2}-\cdots-\theta_{q} \alpha_{t-q}
$$

Keterangan:

$X_{t} \quad$ : deret waktu t

$\alpha_{t-i} \quad:$ kesalahan waktu t-i

$\theta_{t} \quad$ : nilai kesalahan

$\theta_{i} \quad$ : koefisien dari moving average

Autoregressive Moving Average merupakan model kombinasi AR (p) dan MA (q), sehingga dinotasikan sebagai ARMA (p,q), dengan persamaan umum ARMA (p,q) sebagai berikut [9], [15].

$$
X_{t}=\emptyset_{0}+\emptyset_{1} X_{t-1}+\cdots+\emptyset_{p} X_{t-p}+\alpha_{t}-\theta_{1} \alpha_{t-1}-\cdots-\theta_{q} \alpha_{t-q}
$$

Keterangan:

$X_{t} \quad$ : deret waktu t

$X_{t-i} \quad:$ deret waktu t-i

$\alpha_{t-1} \quad$ : nilai kesalahan waktu t-i

$\emptyset_{0} \quad$ : konstanta

$\emptyset_{i} \quad$ : koefisien autoregressive

$\theta_{0} \quad$ : koefisien moving average

Autoregressive Integrated Moving Average data yang digunakan harus sudah stasioner. akan tetapi terdapat juga beberapa data yang tidak stasioner melainkan integrated sehingga perlu dilakukan proses differencing (pembedaan). Data yang sudah diproses differencing selanjutnya diolah dengan ARMA ini merupakan metode ARIMA dengan parameter ARIMA (p,d,q) dengan d adalah banyaknya dilakukan diferensiasi pada data tersebut, dengan persamaan umum ARIMA sebagai berikut [16].

$$
\emptyset_{p}(B)(1-B)^{d} Z_{t}=\theta_{0}+\theta_{q}(B) a_{t}
$$

Keterangan:

$\begin{array}{ll}\emptyset_{p} & \text { : proses autoregressive } \\ \theta_{q} & \text { : proses moving average } \\ (1-B)^{d} & \text { : operator pembeda } \\ d & \text { : tingkat pembeda agar proses menjadi stasioner } \\ B & \text { : operator langakah mundur } \\ Z_{t} & \text { : penyimpangan tehadap rata-rata proses } \\ \alpha_{t} & \text { : nilai kesalahan pada } \mathrm{t} \\ \theta_{0} & \text { : konstanta }\end{array}$

3. Estimasi Parameter

Menentukan model tentatif perlu beberapa tahap estimasi dengan uji kelayakan model untuk mencari model terbaik. Hipotesis dari uji signifikansi sebagai berikut [15].

$H_{o}: \emptyset=0$ (menunjukkan parameter belum signifikansi)

$H_{1}: \emptyset \neq 0$ (menunjukkan parameter sudah signifikansi)

$$
t_{\text {hitung }}=\frac{\widehat{\theta}_{j}}{\operatorname{SE(\widehat {\theta }_{j})}}
$$

Keterangan:

$\hat{\theta}_{j} \quad$ : estimasi dari parameter model autoregressive dan moving average

$S E\left(\hat{\theta}_{j}\right):$ standard kesalahan dari parameter model autoregressive dan moving average 
4. Uji Diagnostik

Pengujian diagnotik digunakan untuk menentukan model tersebut yang layak atau tidak dalam pemilihan model terbaik. Model yang baik dimana hasil residual uji asumsi white noise dengan menggunakan uji Ljung-Boxsebagai berikut [8], [15].

$$
Q=n(n+2) \sum_{k=1}^{i} \frac{\hat{p}_{k}^{2}}{(n-k)}
$$

Keterangan:

$\hat{p}_{k} \quad$ : nilai autokorelasi lag $k$

$Q \quad$ : uji Ljung-Box

$k \quad:$ lag waktu

5. Nilai Akurasi Prediksi

Dalam melakukan peramalan atau prediksi metode yang digunakan tidak bisa menghasilkan prediksi dengan hasil yan tepat. Setiap metode memiliki nilai kesalahan, untuk menghitung kesalahan atau error dapat menggunakan MSE (Mean Square Error) dan MAPE (Mean Absolute Percentage Error), rumus sebagai berikut [14], [23].

$$
M S E=\frac{\sum_{t=1}^{n}\left(Y_{t}-\hat{Y}_{t}\right)^{2}}{n}
$$

Keterangan:

$n$ : banyak data

$Y_{t}:$ data aktual

$\hat{Y}_{t}:$ data prediksi

$$
M A P E=\frac{\sum_{t=1}^{n}\left|P E_{t}\right|}{n}
$$

Dimana,

$$
P E_{t}=\left(\frac{e_{t}}{z_{t}}\right) \times 100
$$

Keterangan:

$P E_{t} \quad$ : persentase kesalahan pada waktu ke-t

$E_{t} \quad$ : nilai kesalahan waktu ke-t

$\hat{Z}_{t} \quad$ : data aktual waktu ke-t

$n \quad$ : banyak data

Mengetahui bahwa prediksi tersebut baik atau buruk dapat diketahui dengan melihat nilai MAPE sebagai berikut.

Tabel 2. Nilai MAPE

\begin{tabular}{cl}
\hline Hasil & \multicolumn{1}{c}{ Keterangan } \\
\hline$<10 \%$ & Hasil prediksi sangat baik \\
\hline $10-20 \%$ & Hasil prediksi baik \\
\hline $20-50 \%$ & Hasil prediksi cukup baik \\
\hline$>50 \%$ & Hasil prediksi buruk \\
\hline
\end{tabular}

6. Suatu model ARIMA yang memenuhi syarat prediksi, maka dapat dilakukan prediksi pada waktu yang akan datang menggunakan model yang terpilih. 


\section{HASIL DAN PEMBAHASAN}

Berdasarkan Tabel 1 untuk menentukan model ARIMA dari data tersebut dilakukan plot time series untuk mengidentifikasi stasioneritas dari data.

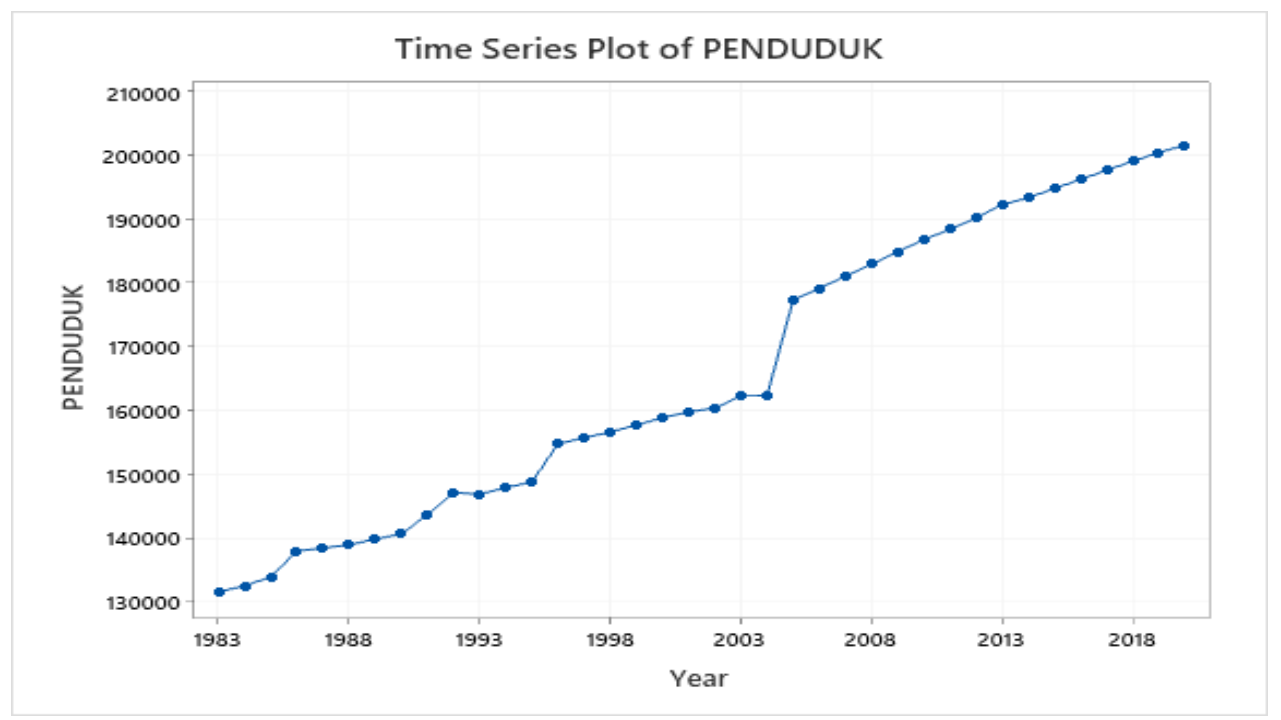

Gambar 1. Plot data jumlah penduduk Kota Pasuruan

Pada Gambar 1 memperlihatkan bahwa plot data menunjukkan tren naik (positif) dikarenakan dari tahun 2005 sampai 2009 mengalami kenaikan, sehingga data tersebut belum stasioner. data dapat dikatakan stasioner jika tidak terdapat perubahan kenaikan dan penurunan dalam varians dan rata-ratanya.

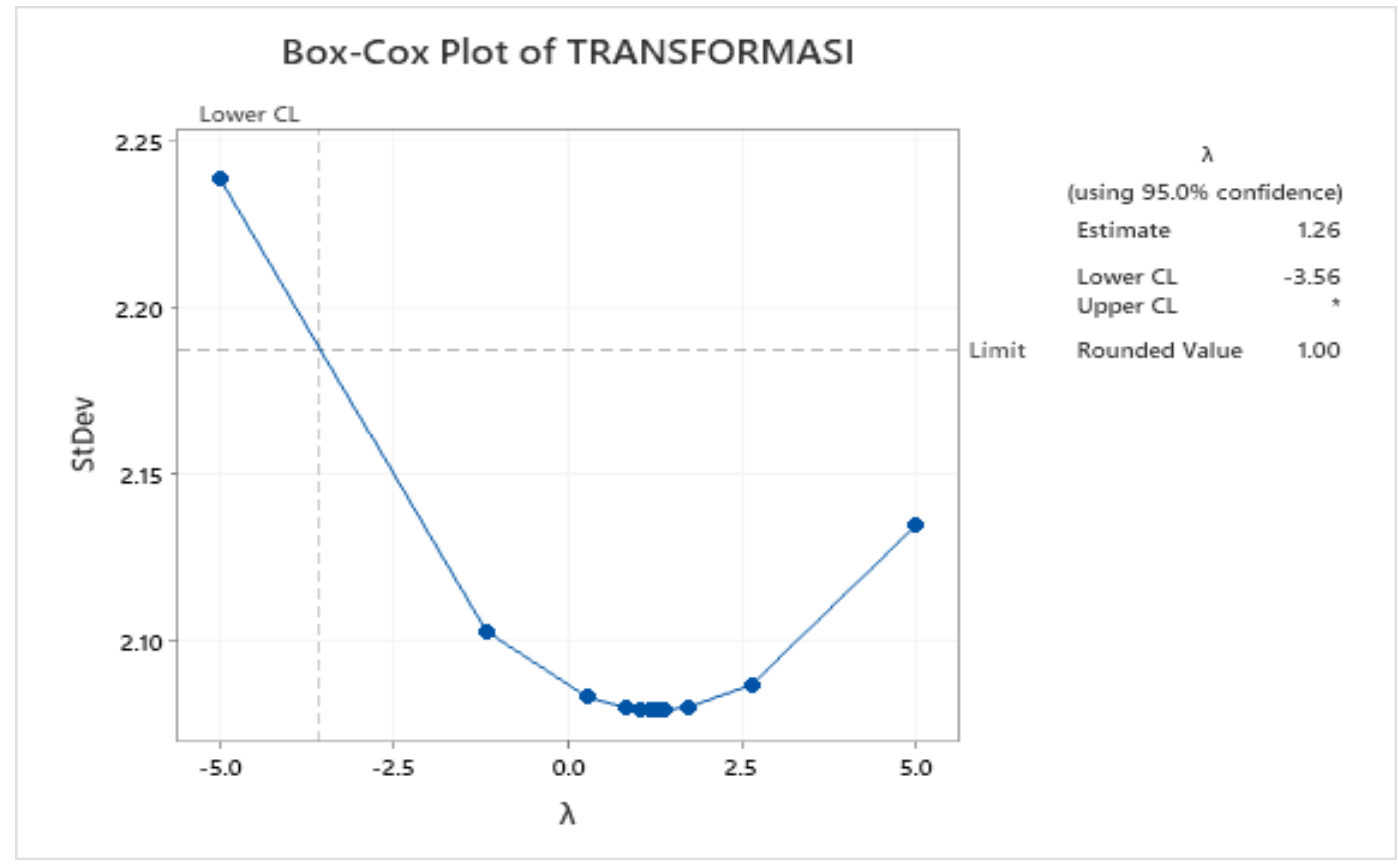

Gambar 2. Plot Box-Cox data transformasi

Stasioner data terhadap varians menggunakan Box-Cox ransformasi, stasioner dalam varians dapat ditentukan dengan nilai lamda (rounded value) sama dengan 1. Pada Gambar 2 memperlihatkan bahwa nilai lamda sama dengan 1, dapat dikatakan data tersebut sudah stasioner dalam varians. Stasioner data terhadap rata-rata (mean) bisa dilihat dari plot ACF dan plot time series. Dari plot time Series data tersebut belum memiliki pola yang tetap. 


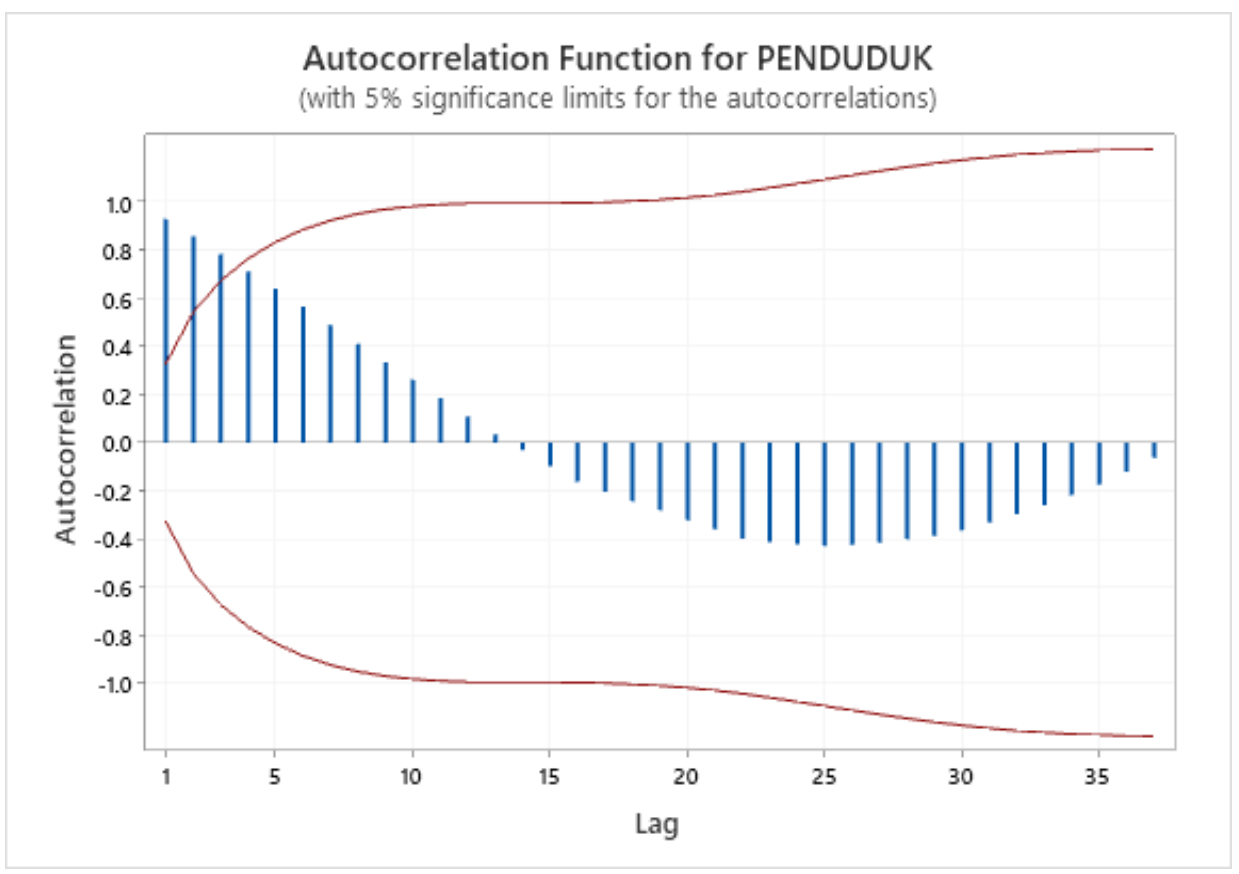

Gambar 3. Plot ACF jumlah penduduk Kota Pasuruan

Pada Gambar 3 memperlihatkan bahwa lag 1 sampai lag 3 melebihi garis signifikansi atau garis kepercayaan, sehingga data tersebut belum stasioner. Akibatnya, perlu proses differencing supaya data tersebut stasioner terhadap rata-rata (mean).

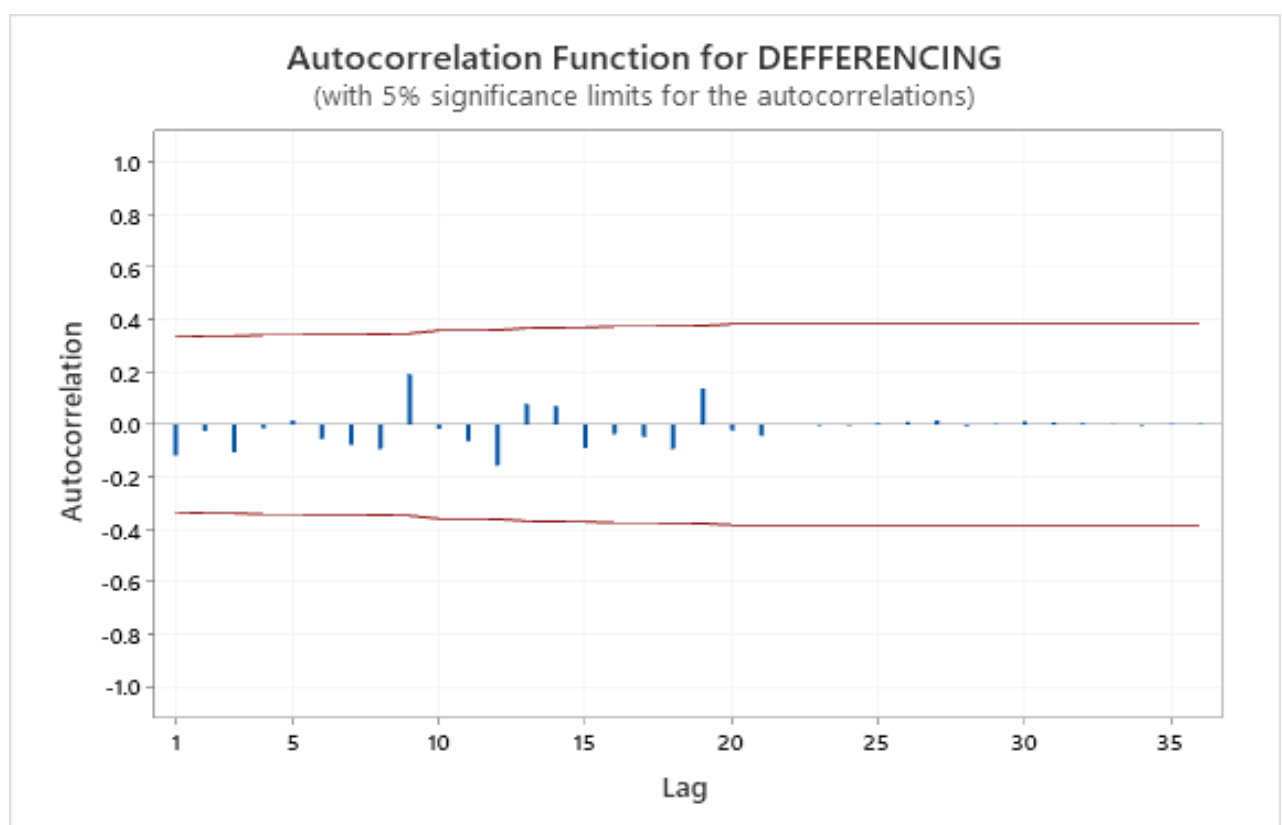

Gambar 4. Plot ACF setelah differencing

Berdasarkan Gambar 4 memperlihatkan bahwa tidak ada lag yang melewati garis signifikansi atau garis kepercayaan, sehingga data tersebut dapat dilakukan stasioner terhadap rata-rata (mean). Jika data sudah stasioner maka selanjutnya melakukan plot fungsi autokorelasi (PACF). 


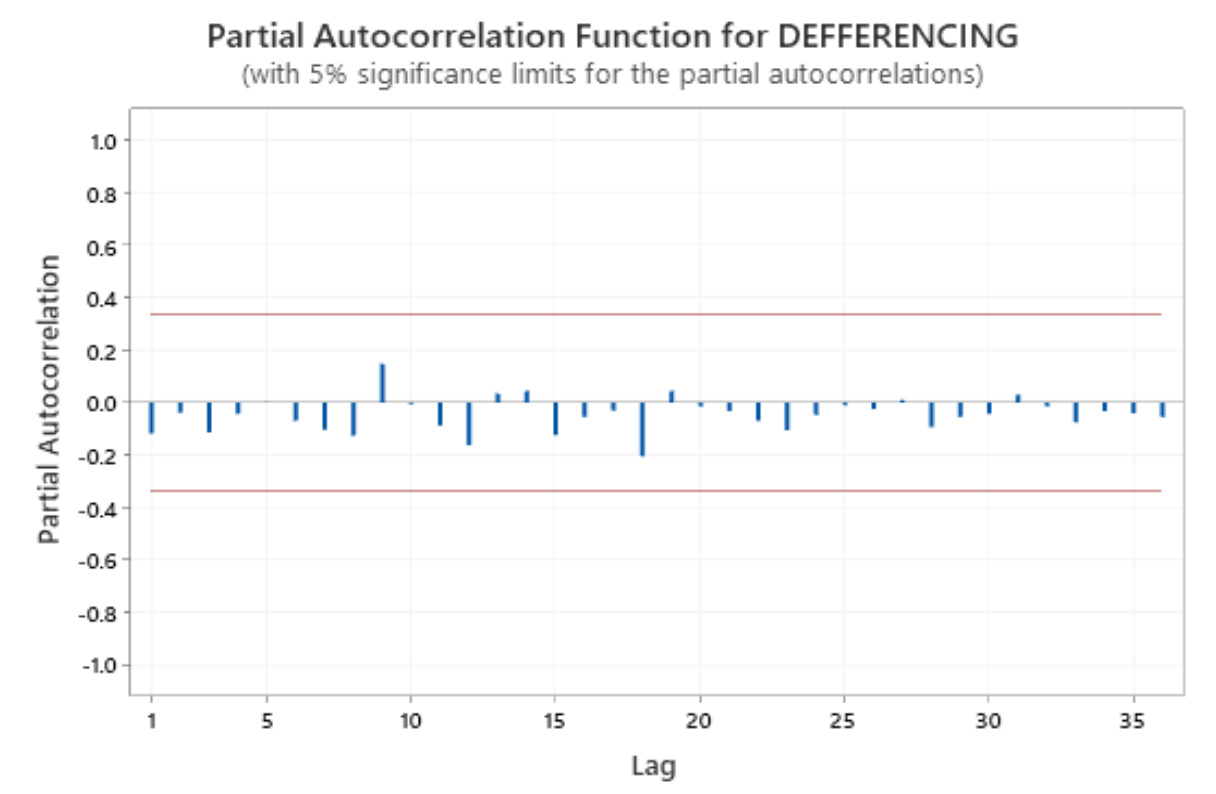

Gambar 5. Plot PACF setelah differencing

Berdasarkan Gambar 5 untuk mengetahui model ARIMA tentatif atau sementara. Berdasarkan plot ACF dan PACF memperlihatkan bahwa plot tersebut tidak terdapat autokorelasi pada model, sehingga nilai $\mathrm{MA}(\mathrm{q})=0$ dan $\operatorname{AR}(\mathrm{p})=0$, maka diperoleh model tentatif ARIMA $(0,1,0)$. Model tersebut adalah random walk dimana koefisien autokorelasi sama dengan 1, sehingga model tentatif ARIMA adalah ARIMA model $(1,1,0)$, ARIMA model $(0,1,1)$ dan ARIMA model $(1,1,1)$.

Untuk memilih model yang akan digunakan dalam prediksi dilakukan uji signifikansi dan uji residual white noise. Uji signifikansi parameter dengan mengetahui nilai $p$-value jika nilai $p$-value kurang dari 0.05 maka model tersebut sudah signifikan. Hasil uji signifikansi tentatif ARIMA model $(1,1,0)$, ARIMA model $(0,1,1)$ dan ARIMA model $(1,1,1)$ sebagai berikut:

Tabel 3.Hasil Uji Signifikansi

\begin{tabular}{cccccc}
\hline Model & Parameter & Coef & SE Coef & T-Value & P-Value \\
\hline ARIMA $(1,1,0)$ & AR $(1)$ & 0.301 & 0.159 & 1.89 & 0.067 \\
\hline ARIMA $(0,1,1)$ & MA (1) & -0.197 & 0.164 & -1.20 & 0.236 \\
\hline ARIMA $(1,1,1)$ & AR (1) & 1.0006 & 0.0234 & 42.70 & 0.000 \\
\hline & MA (1) & 0.9831 & 0.0953 & 10.32 & 0.000 \\
\hline
\end{tabular}

Berdasarkan Tabel 3 memperlihatkan bahwa ARIMA model $(1,1,0)$ dan ARIMA model $(0,1,1)$ belum signifikan karena nilai $p$-value lebih dari 0.05 , ARIMA model $(1,1,1)$ signifikan karena nilai $p$-value kurang dari 0.05. setelah melakukan uji signifikansi parameter, perlu dilakukan uji residual white noise untuk mengetahui model yang akan digunakan untuk prediksi. Dalam melakukan uji residual menggunakan LjungBox. Jika nilai $p$-value lebih dari 0.05 maka model tersebut memenuhi syarat white noise. Hasil uji LjungBox untuk ARIMA model $(1,1,0)$, ARIMA model $(0,1,1)$ dan ARIMA model $(1,1,1)$.

Tabel 4. Hasil Uji Ljung-Box

\begin{tabular}{ccccc}
\hline Model & Lag & Chi-Square & DF & P-Value \\
\hline ARIMA $(1,1,0)$ & 12 & 10.03 & 11 & 0.528 \\
\cline { 2 - 5 } & 24 & 14.65 & 23 & 0.907 \\
\cline { 2 - 4 } & 36 & 14.71 & 35 & 0.999 \\
\hline \multirow{2}{*}{ ARIMA $(0,1,1)$} & 12 & 8.55 & 11 & 0.663 \\
\cline { 2 - 5 } & 24 & 12.76 & 23 & 0.957 \\
\cline { 2 - 5 } & 36 & 12.85 & 35 & 0.000 \\
\hline ARIMA (1,1,1) & 12 & 5.51 & 10 & 0.992 \\
\cline { 2 - 5 } & 24 & 9.28 & 22 & 1.000 \\
\hline
\end{tabular}


Berdasarkan Tabel 4 setelah dilakukan pengujian Ljung-Box memperlihatkan bahwa ARIMA model $(1,1,0)$, ARIMA model $(0,1,1)$ dan ARIMA model $(1,1,1)$ bersifat white noise karena nilai $p$-value lebih dari 0.05. setelah melakukan uji white noise, menentukan nilai MSE dan MAPE dari model sementara ARIMA.

Tabel 5. Nilai MSE dan MAPE

\begin{tabular}{ccc}
\hline Model & MSE & MAPE \\
\hline ARIMA $(1,1,0)$ & 13.9426 & $2.22 \%$ \\
\hline ARIMA $(0,1,1)$ & 14.4204 & $2.21 \%$ \\
\hline ARIMA $(1,1,1)$ & 10.0561 & $1.52 \%$ \\
\hline
\end{tabular}

Berdasarkan Tabel 3, Tabel 4, Tabel 5 model ARIMA yang parameternya signifikan dan memenuhi asumsi white noise merupakan ARIMA model $(1,1,1)$ dengan nilai MSE dan MAPE yang terkecil. Setelah memilih model terbaik, selanjtnya dilakukan prediksi jumlah penduduk Kota Pasuruan.

Tabel 6. Prediksi jumlah penduduk

\begin{tabular}{cc}
\hline Tahun & Jumalah Penduduk \\
\hline 2020 & 203221 \\
\hline 2021 & 205815 \\
\hline 2022 & 208262 \\
\hline
\end{tabular}

Berdasarkan Tabel 6 prediksi jumlah penduduk Kota Pasuruan tahun 2020 sampai 2022 memiliki hasil prediksi yang akan terus meningkat, pada tahun 2020 prediksi jumlah penduduk sebesar 203.646 jiwa, tahun 2021 sebesar 205.731 jiwa, tahun 2022 sebesar 207.817 jiwa. Penelitian ini memiliki hasil prediksi yang bersesuaian dengan penelitian sebelumnya terdapat pada penelitian tentang peramalan pertumbuhan penduduk yang menggunakan metode ARIMA, deret aritmatik, deret geometri dan deret eksponensial menunjukkan bahwa hasil prediksi jumlah penduduk yang lebih mendekati data aktual dengan menggunakan metode aritmatik, dan hasil peramalan menggunakan metode ARIMA hasilnya jauh dari data aktualnya. Hasil prediksi yang jauh dari data aktualnya, karena dalam melakukan prediksi menggunakan metode ARIMA data yang digunakan sebagai sample minimal 50 data dan pada penelitian ini model sementara ARIMA adalah random-walk yang kurang mampu untuk memprediksi jangka panjang.

Berdasarkan data Badan Pusat Statistik, jumlah penduduk Kota Pasuruan pada tahun 2020 sebesar 208.006 jiwa. Sementara itu hasil prediksi jumlah penduduk Kota Pasuruan pada tahun 2020 sebesar 203.646 jiwa. Berdasarkan fakta tersebut, dapat dilihat terjadi perbedaan yang cukup jauh yaitu sejumlah 4360 . Perbedaan ini dapat dipengaruhi beberapa faktor. Faktor kondisi pandemi yang sedang merebak ternyata tidak berpengaruh signifikan terhadap jumlah penduduk di Kota Pasuruan. Dimana berdasarkan berita yang termuat dalam pasuruankota.go.id, Kota Pasuruan merupakan kota dengan peringkat paling bawah untuk jumlah kasus yang terinfeksi Covid-19, yaitu 32 kasus [24].

\section{KESIMPULAN}

Berdasarkan penjelasan dari hasil penelitian mengenai prediksi jumlah penduduk Kota Pasuruan menggunakan metode ARIMA dapat diambil kesimpulan bahwa model terbaik untuk melakukan prediksi jumlah penduduk Kota Pasuruan adalah ARIMA $(1,1,1)$. Hasil prediksi jumlah penduduk Kota Pasuruan sebesar 203.646 jiwa dengan MSE sebesar 10.542507 dan MAPE sebesar 1,52\%.

\section{UCAPAN TERIMA KASIH}

Terima kasih kepada Badan pusat Statistik Kota Pasuruan yang sudah memberikan kesempatan untuk lebih mengenal dunia pekerjaan dan ilmu yang bermanfaat sehingga peneliti dapat menyusun jurnal ini. Terima kasih kepada dosen pembimbing, dosen lapangan serta semua pihak yang telah membantu dalam menyusun jurnal ini. Peneliti berharap jurnal ini dapat bermanfaat bagi semua pihak. 


\section{DAFTAR PUSTAKA}

[1] W. Widyatmanti and D. Natalia, Geografi untuk SMP dan MTS VIII. Jakarta: Garsindo, 2008

[2] Mulyadi, Ekonomi Sumber Daya Manusia dalam Perspektif Pembangunan. Jakarta: Raja Grafindo Persada, 2014.

[3] Subandi, Ekonomi Pembangunan. Bandung: Alfa Beta, 2014.

[4] A. B. Saputro, "Peramalan Pertumbuhan Penduduk Per Kecamatan Di Kabupaten Kediri Menggunakan Metode Kuadrat Terkecil," Skripsi, Nusantara Persatuan Guru Republik Indonesia, 2016.

[5] B. P. Statistika, "Penduduk Indonesia Hasil SP 2020," 2021 [Online] Tersedia: www.bps.go.id [Diakses 27 Januari 2021].

[6] B. P. S. Jawa Timur, Provinsi Jawa Timur dalam Angka 2020. PT. Sinar Murni Indo Printing, 2020.

[7] B. P. S. K. Pasuruan, Kota Pasuruan dalam Angka 2020. 2020 [Online] Tersedia: https://pasuruankota.bps.go.id [Diakses 27 Januari 2021].

[8] Haslina, Hasmah, K. W. Fitriani, M. Asbar, and Asrirawan, "Penerapan Metode ARIMA (Autoregressive Integrated Moving Average) Box Jenkins untuk Memprediksi Pertambahan Jumlah Penduduk Transmigran (Jawa dan Bali) di Kecamatan Sukamaju, KabupatenLuwu Utara Propinsi Sulawesi Selatan,”J. Bus. Ethics, vol. 09, no. 1, pp. 55-67, 2018.

[9] T. Rahmawati, L. Sudarmana, and A. Priyanto, "Penerapan Metode Arima Box-Jenkins Untuk Peramalan Konsumsi Listrik," vol. XIX, no. 1, pp. 6-11, 2020.

[10] Raihan, M. S. Eff, and A. Hendrawan, "Forecasting Model Eksponensial Smoothing Time Series Rata Rata Mechanical Availability Unit Off Highway Truck Cat 777D Caterpillar," Poros Tek., vol. 8, no. 1, pp. 1-9, 2016.

[11] D. Wiyanti and R. Pulungan, "Peramalan Deret Waktu Menggunakan Model Basis Radial (RBF) dan Autoregressive Integrated Moving Average (ARIMA)," vol. 35, no. 0215, pp. 175-182, 2012.

[12] M. L. Tauryawati and M. I. Irawan, "Perbandingan Metode Fuzzy Time Series Cheng dan Metode Box-Jenkins untuk Memprediksi IHSG," J. Sains dan Seni ITS, vol. 3, no. 2, pp. A34-A39, 2014.

[13] N. Artanto and A. Agoestanto, "Perbandingan Peramalan Curah Hujan Dengan Metode," vol. 4, no. 1, 2015.

[14] E. Munarsih, "Peramalan Jumlah Pengangguran di Provinsi Sumatera Selatan dengan Metode Autoregressive Integreted Moving Average (ARIMA)," J. Penelit. Sains, vol. 19, no. 1, p. 168439, 2017.

[15] T. Yunita, "Peramalan Jumlah Penggunaan Kuota Internet Menggunakan Metode Autoregressive Integrated Moving Average ( ARIMA )," J. Math. Theory Appl., vol. 1, no. 2, pp. 16-22, 2019.

[16] I. S. Wulandari, N., Setiawan, \& Ahmad, "Peramalan Inflasi Kota Surabaya dengan Pendekatan ARIMA, Variansi Kalender, dan Intervensi,” J. Sains Dan Seni Its, vol. 5, no. 1, 2016.

[17] As'ad, I. M. Tirta, and Y. S. Dewi, "Peramalan pertumbuhan penduduk kabupaten situbondo dengan model arima, deret aritmatik, deret geometri dan deret eksponensial," vol. 4, pp. 141-152, 2013.

[18] F. Fejriani, M. Hendrawansyah, L. Muharni, S. F. Handayani, and S. Syaharuddin, "Forecasting Peningkatan Jumlah Penduduk," Geogr. J. Kajian, Penelit. dan Pengemb. Pendidik., vol. 8, no. 1, pp. 27-36, 2020.

[19] N. Salwa, N. Tatsara, R. Amalia, and A. F. Zohra, "Peramalan Harga Bitcoin Menggunakan Metode ARIMA (Autoregressive Integrated Moving Average)," J. Data Anal., vol. 1, no. 1, pp. 21-31, 2018.

[20] A. H. Hutasuhut, W. Anggraeni, and R. Tyasnurita, "Pembuatan Aplikasi Pendukung Keputusan untuk Peramalan Persediaan Bahan Baku Produksi Plastik Blowing dan Inject," J. Tek. Pomits, vol. 3, no. 2, p. A169,A174, 2014.

[21] H. Hartati, "Penggunaan Metode Arima Dalam Meramal Pergerakan Inflasi," J. Mat. Sains dan Teknol., vol. 18, no. 1, pp. 110, 2017, doi: 10.33830/jmst.v18i1.163.2017.

[22] K. F. Azriat, A. Hoyyi, and M. A. Mukid, "Verifikas Model ARIMA Musiman Menggunakan Peta Kendali Moving Range," GAUSSIAN, vol. 3, no. 4, pp. 701-710, 2014.

[23] R. Prameswari, "Peramalan Ekspor Kendaraan Bermotor di Indonesia Metode ARIMA (Autoregressive Integrated Moving Average) Box Jenkins," Skripsi, UIN Sunan Ampel Surabaya, 2020.

[24] PasuruanKota, "Kasus Konfirmasi AKtif Covid-19 Kota Pasuruan Terendah Se- Jawa Timur," 2021, [Online]. Tersedia: http://pasuruankota.go.id/2021/01/12/kasus-konfirmasi-aktif-covid-19-kota-pasuruan-terendah-se-jawa-timur/ [Diakses: 27 Januari 2021]. 